\title{
The crisis in leadership in the context of the nursing shortage and the increasing prevalence of nursing unions
}

This article was published in the following Dove Press journal:

Journal of Healthcare Leadership

25 October 2012

Number of times this article has been viewed

\section{Latisha L Balogh-Robinson}

Marist College, School of Global and Professional Programs, Poughkeepsie, NY, USA
Correspondence: Latisha L BaloghRobinson

Marist College, School of Global and

Professional Programs, 3399 North Road, Poughkeepsie, NY I260I, USA

Tel + I 8456779960

Email latisha.balogh-robinson I@marist.edu
Abstract: Developing nurse leaders in a unionized environment presents unique challenges that are beyond those traditionally experienced in nonunion settings. This literature review examines multiple factors contributing to increasing nursing union membership, including population aging, the nursing shortage, and the relationship between leadership and staff engagement. Current trends in succession planning and leadership development are also highlighted. Job dissatisfaction related to the inability to provide quality care in the context of a protracted nursing shortage and current health care trends is identified as the driver in nursing union growth. The discussion that follows assumes current trends in nursing unionization will continue and proposes that adversarial relationships between management and union nurses will further amplify the dearth in leadership by reducing the pool of nurses willing to leave the union for nonunion leadership roles.

Keywords: succession planning, baby boomer, staff engagement, population aging

\section{Introduction}

This paper initially set out to identify the psychosocial barriers existing in unionized health care environments that make it difficult for a nurse to leave the bedside and the bargaining unit to pursue leadership opportunities in the same organization in which he/she was previously a union member. However, what the literature review revealed instead were multiple, seemingly unrelated factors that appear to be on a slow motion collision course; if left unaddressed, these are likely to result in a leadership crisis in the health care industry in the coming decades. The nursing shortage, the lack of succession planning and frontline leadership development in health care organizations, and the increasing prevalence of nursing unions are phenomena that have been heading down separate, yet converging paths for a long time. However, what makes this moment in the current trajectory most hazardous is the unforgiving social and economic landscape.

\section{The baby boom}

According to the 2010 US Census Bureau report, 40.3 million people, $13 \%$ of the population, are currently aged over 65 years old. ${ }^{1}$ This number is expected to nearly double by 2030. It is further projected that one in every five Americans will be over the age of 65 by the year $2050 .^{2}$ The 2010 census report also advises that between the years 2000 and 2010, the population of baby boomers - people born between 1946 and 1964 - grew $31.5 \%$, while the growth rate of the 18-44-year-old age group increased 
by only $0.6 \%$. The oldest of the baby boomers begun to reach retirement age in $2008 .^{2}$ America is graying, and the leading edge of the age wave has already reached our shores.

The potential impact of the social, political, and economic predictions related to the aging of America is profound. Just as young boomers flooded public school systems between 1955 and $1975,{ }^{2}$ aging boomers will continue to stress the limits of social systems and resources as they transition through each developmental phase in their lives and livelihoods. Economists and political scientists worry that baby boomers threaten our national fiscal solvency by availing themselves, en masse, of entitlement programs put in place to support our citizens as they reach retirement age. Corporate America is likewise concerned, and with good reason. According to US General Accounting Office predictions, the number of workers aged 55 years and older will soon balloon by $73 \%{ }^{3}$ Furthermore, a study of executives and young professionals in both private and nonprofit organizations revealed that the majority of organizational leaders were aged 50 to 69 years old and were much closer to retirement than those who were "anticipating a long career." With the rapidly aging workforce and turnover of executive directors projected to be upward of $70 \%$ within the next 4 to 5 years, ${ }^{5}$ corporate America will be challenged by both a shortage of labor and a short supply of qualified leaders.

Carman et al report that the business sectors hardest hit by attrition due to aging are accounting, insurance, law, real estate, medicine, and nursing. ${ }^{5}$ The health care industry in general, and nursing specifically, will be particularly challenged by the complex and multifaceted repercussions presented by an aging population. Not only are baby boomers disproportionately represented in the nursing profession compared with the workforce in general, ${ }^{2}$ but also, as boomers age, they will require health care services due to age-related health conditions, which will further amplify the effects of a shrinking nursing workforce.

The nursing shortage is linked to decreased job satisfaction among nurses and, in turn, decreased job satisfaction is linked to collective bargaining activity in the health care industry. Although significant parallel research is devoted to both the impact of the nursing shortage on nursing leadership and practice, and the influence of nursing unions in the context of organizational leadership and communication, little attention has been devoted to the compounded effects of the nursing shortage and union membership on the leadership development of frontline staff nurses.

This literature review seeks to identify the barriers a union environment imposes on health care organizations' ability to identify and groom union nurses who possess leadership potential for nonunion leadership roles within the organization. It also identifies the health care industry's underutilization of succession planning and formal leadership development programs as co-contributors to the pending leadership crisis. The discussion that follows attempts to provide answers to key questions leadership should ask if it holds any hope of successfully negotiating the rough road that lies ahead. The state of leadership in the health care industry is in jeopardy, but leadership remains in the driver's seat. With clear insight into the issues, and given the appropriate responses, a crisis in leadership may be averted by increasing the pool of nurses who are not only able but willing to seek leadership roles outside of the bargaining unit.

\section{Literature review}

\section{The nursing shortage}

There have been several cyclic episodes of nursing shortages since World War II, many of which have been relatively short lived and their resolution(s) tenably achieved via tactics such as benefit incentives, wage adjustments, and the recruitment of foreign-born nurses. ${ }^{6}$ Unfortunately, there is nothing simple or short lived about the current nursing shortage, and the traditional short-term solutions, such as wage increases and bonus packages, are likely to have little, if any, lasting effect on the long-term adequacy of the nursing workforce. $^{\text {? }}$

Although there are slight differences in the details regarding the timing, duration, and specific statistics related to the impact predictions of the nursing shortage, experts agree that "nursing is currently on the brink of what might be the most significant and enduring nursing shortage in the US." What differentiates the current nursing shortage from previous shortages is the number of variables contributing to the complexity of the problem. Not only are there more nurses retiring than there are entering the workforce, there is also a decreased capacity to educate and train enough new nurses to fill the deficit. ${ }^{6}$ Further compounding the effects of the nursing shortage is the increased health care demands of a simultaneously aging population. Couple these effects with the financial uncertainty imposed on the health care industry by state and federal government policy and an increasingly complex, physically demanding, and stressful work environment,, $8-11$ and the conditions for a "perfect storm"12 are in place for a protracted nursing shortage.

However, one does not have to look beyond the 2010 US Census Bureau report to realize that the current nursing shortage is real and expected to become more severe 
around $2015 .{ }^{13}$ More optimistic predictions that take into account the recent surge of younger nurses entering the workforce, inactive nurses returning to the bedside, and older nurses deferring retirement due to the effects of the economic recession suggest that a shortfall in nursing full-time equivalents will develop later than previously anticipated and will occur around 2018. ${ }^{14,15}$ Buerhaus et al further predict that the current shortage will peak later than previously anticipated in $2025 .{ }^{14}$ Once again, there may be disagreement regarding the details of the timing and life cycle of the current nursing shortage, but there is overwhelming consensus that the shortage is here and it will worsen before it improves.

The most formidable variable contributing to this crisis is the aging demographic on both the supply and the demand sides of the current nursing shortage. ${ }^{16}$ The US workforce is graying and the median age has been steadily increasing. ${ }^{17}$ The median age of the US labor force in 1986 was 35.4 years old; in 2006 the median age was 40.8 years and in 2016 the median age is projected to be 42.1 years. ${ }^{18,19}$ However, even as the general labor force ages, the literature reveals that the nursing workforce is aging more quickly in comparison., ${ }^{2,13,20}$ In support of this, Buerhaus et al suggest that there was a 4.5-year age increase in the nursing workforce, more than twice the rate of other occupations combined, between 1983 and $1998 .{ }^{20}$ The average age of a nurse, in spite of a recent surge in nurses aged 23-35 years old entering the workforce, is conservatively estimated at 43.8 years. ${ }^{14}$ The 2008 National Sample Survey of Registered Nurses, ${ }^{21}$ released in September 2010, differs from Buerhaus et al's estimate in reporting that the current average age of registered nurses ( $\mathrm{RNs}$ ) is estimated to be higher, at 47.0 years. ${ }^{22}$ Although a 3.2-year difference in the age estimates may seem statistically significant, there is a general consensus among scholars that nurses aged in their 50s are expected to comprise the largest segment of the nursing workforce as early as 2012-2015..$^{14,20,22-24}$

Nurses represent the largest segment of the health care industry. ${ }^{11}$ According to the US Bureau of Labor Statistics, in 2008 nurses occupied upward of 2.6 million jobs, $60 \%$ of which are located in the acute care setting. ${ }^{24}$ Current projections factoring in recent economic trends suggest that the proportion of older nurses in the workforce will steadily increase and peak around 2015. At that point, $36.4 \%$ of the nursing workforce is projected to be aged 50-64 years old. ${ }^{14}$ These statistics are cause for concern due to the number of nurses who intend to retire in the near future. In 2003, an American Nurses Association (ANA) online survey revealed that over $82 \%$ of nurses who were over the age of 40 planned to retire within the following 20 years. ${ }^{13}$ The ANA's findings are further supported by the 2006 Nursing Management Aging Workforce Survey, ${ }^{25}$ which shows that a full 55\% of the nurses surveyed intend to retire between 2011 and 2015. ${ }^{6,22}$ Another survey of 1773 nurses also supports the ANA's finding and reveals that $66 \%$ of respondents planned to leave the workforce within 5 years and $61 \%$ reported plans to leave the profession within 10 years. ${ }^{26}$ Given the prominent segment of the health care industry occupied by acute care nurses, combined with the projected age and the retirement intentions of this aging cohort, there is an increasingly more urgent need to find a solution to this complex problem.

\section{Prediction forecast for nurse vacancy rates}

The US Health and Human Services calculates the projected nurse vacancy rate at approximately 1.1 million by $2020 .^{27,28}$ Buerhaus presents a more conservative estimate in predicting that the number of open RN positions in the USA between 2005 and 2020 will quadruple to reach upward of 500,000 vacancies. ${ }^{29}$ Buerhaus et al have since recalculated their previous estimates, taking into account the current surge in nurse recruitment and retention attributed to the effects of economic recession, and projected a much lower and slower deficit of 260,000 RN vacancies by $2025 .{ }^{14}$ They are quick to warn, however, that the more optimistic vacancy projection is still very severe and represents a nursing deficit twice that of any shortage experienced in the USA since the mid-1960s.

\section{Proposed solutions}

Whether the projected nursing vacancies reach the conservative or the extreme projections, it is clear that both short-term and long-term plans must be put in place to buffer the effects of the current shortage. Scholars and policy makers alike have proposed several solutions to strengthen the current nursing workforce and fill the pipeline with a sufficient supply of nurses that will meet the growing health care demands of an aging population. These proposals include, but are not limited to, increasing the number of nursing graduates, bolstering the retention of older nurses, increasing the number of foreign-born nurses by recruiting from overseas, and tapping into the dormant population of RNs who continue to maintain their license but are no longer practicing. Although each of these proposals has merit, they also have associated problems that warrant further discussion.

A natural response to any nursing shortage is a universal call for increased public interest in nursing as a profession and to increase enrollment in nursing programs. At face value, this solution seems straightforward; however, research shows that the 
number of available seats in nursing programs not only falls short in meeting current demands but also will not be able to meet the anticipated increased demands should nursing programs be expected to produce enough new graduate nurses to offset the rapidly growing deficit. According to the American Association of Colleges of Nursing, in 2010-2011, nursing programs in the USA turned away over 67,563 qualified applicants from bachelor and master of science in nursing programs due to insufficient faculty, training sites, and state budget cuts. ${ }^{14,22}$ Recruiting and retaining nursing faculty has become especially challenging. ${ }^{16}$ As previously stated, the data from the 2008 National Sample Survey of Registered Nurses reports that the average age of a bedside nurse is 47 . The same study also reports that the average age of nursing faculty is currently 57 years. ${ }^{22}$ Many of the same forces that are driving the nursing shortage are also driving the shortage of nursing faculty. In addition to an aging faculty reaching retirement age, far fewer nurses are considering teaching as a viable career choice, not only because the pay is not competitive in comparison with bedside nursing, but also because it is not commensurate to the level of education required to teach. $22,30,31$

In the past, when nursing schools were unable to meet the demands to fill nursing vacancies, immigration was called upon to fill the remaining gap. ${ }^{20,32,33}$ Several problems, logistical and ethical, surface when looking overseas for the solution to the US nursing shortage. Population aging and nursing shortages are worldwide phenomena, ${ }^{2,3,34}$ and the proportion of the US population that is 65 years old and older is considerably smaller than that of other industrialized nations. ${ }^{2}$ That being said, it is reasonable to assume the pool of qualified foreign-born nurses will be in short supply, and if the USA is indeed successful in recruiting from overseas, this will be at the health and intellectual expense of the contributing nations.

Some researchers believe that the best solution to the nursing shortage lies in convincing older nurses to postpone their retirement and motivating inactive nurses to return to the bedside. Although there is disagreement among scholars regarding the existence and/or viability of an inactive nursing workforce that are available to return to the bedside, ${ }^{35,36}$ the value of retaining the skills, knowledge, and expertise held by more experienced nurses is undeniable. However, the fact remains that postponing retirement may simply be postponing the inevitable exodus of a large cohort of aging professionals.

\section{Succession planning: what planning?}

In the course of her discussion regarding succession planning and the importance of nurse leaders grooming their own replacements, Stichler asserts that "[t]he effective leader is [the] one who can step out of the water and not leave a ripple." ${ }^{37}$ While this ideal is true in principle, even the best leaders, when leaving in large numbers, will not only cause ripples but will also drop the water level precipitously. The sobering impact predictions regarding the imminent exodus of baby boomers from the workforce have caught the attention of organizational leaders across disciplines and have likewise prompted an increased interest in succession planning. ${ }^{3,5,10,37,38}$ The health care industry is no exception. Unfortunately, however, when it comes to leadership succession planning, nursing's track record is said to be "historically scarce or nonexistent."39

According to the US Government Accountability Office, $62 \%$ of hospitals in the USA in 2005 were operated as nonprofit organizations. ${ }^{40}$ Carman et al conducted a multimethod study of 110 nonprofit organizations in North Carolina and found that only $25 \%$ of the participating nonprofits had a succession plan of any kind. ${ }^{5}$ The health care industry fairs even worse than nonprofits in general. According to a study commissioned by the American College of Healthcare Executives conducted in 2007, only 21\% of hospitals in the USA reported having structured succession plans or a formal process of identifying and developing internal candidates for promotion to senior leadership positions. ${ }^{41}$ In a larger global context, a benchmarking study that included input from 4500 leaders employed in over 900 organizations found that $55 \%$ of organizations report having succession plans but only $28 \%$ of all leaders, regardless of managerial level, report being supported by a structured succession management plan. ${ }^{3}$ Barnett and Davis report that most organizational leaders feel that "succession planning efforts are [either] inadequate or simply broken." ${ }^{38}$ Bernthal and Wellins' research results support Barnett and Davis' findings and report that an alarming one-third of all existing organizational succession plans are deemed ineffective and did not show improvement in the 2 years preceding the study. The literature consistently shows that structured and formalized succession plans, although increasingly recognized as being invaluable and necessary to prevent organizational disruption, or a "widespread leadership crisis," 42 and proven to promote a better overall business performance, ${ }^{3}$ are not being implemented to their fullest potential, if at all.

Only $25 \%$ of organizations that do have formalized succession plans include frontline leadership in those plans. ${ }^{3}$ The literature reveals that current research exploring issues related to succession planning is primarily focused 
on executive- and/or senior-level leadership and nearly excludes that relating to middle and frontline management. Although the literature anecdotally warns against focusing succession planning efforts entirely on executive- and senior-level management and acknowledges the importance of the frontline manager's role in communicating and achieving organizational goals $\mathrm{s}^{3,43}$ as well as driving employee engagement, ${ }^{44}$ there is a comparatively small body of literature promoting an organizational approach that extends succession planning to frontline leadership and beyond. What is material to this discussion is the recognition that traditional methods of talent management and succession planning, which include either doing nothing or relying on "complex bureaucratic models for forecasting" dating from the $1950 \mathrm{~s}$, are no longer satisfactory in meeting the needs of a rapidly changing workforce demographic. ${ }^{43}$ Not surprisingly, as the nursing shortage is quickly devolving into a nursing crisis, nursing scholars, executives, and professionals have begun to recognize the enormous value succession planning can have to the health care organization and have also begun to include this discourse in professional nursing journals.

\section{The state of nursing leadership}

Given the increased financial pressures to improve the quality of care delivery in hospitals by the Centers for Medicare and Medicaid Services by linking patient outcomes and patient satisfaction to reimbursement schedules, ${ }^{45,46}$ health care organizations are increasingly reliant on effective leadership of not only frontline managers but also bedside nurses to achieve these important industry-wide goals.

Evidence shows that there is a direct relationship between effective leadership and organizational performance. In reviewing the results of two extensive studies involving a combined 227,631 health care providers, Hewison found that hospitals with effective senior leadership resulted in fewer patient complaints, reduced mortality, better quality of care delivery, and improved teamwork. ${ }^{47}$ Hewison further noted that positive perceptions of leadership had a direct association with staff experiencing a better work-life balance, improved morale and job satisfaction, and being less likely to indicate intention to leave. Hewison's findings are supported by a Swedish study ${ }^{48}$ involving 77 nurse managers and ten of their subordinates. Sellgren et al concluded that there is a strong correlation between the nursing managers' leadership behavior, staff turnover, and job satisfaction..$^{48}$ Han and Jekel likewise conducted a study investigating the mediating effects of job satisfaction on leader-member exchange and nurse turnover intentions. ${ }^{12}$ Han and Jekel's findings further support those of Sellgren et al and reinforce the significance of the role of the manager in employee satisfaction and the reduction of intention to leave. In a different study focusing on the relationship between RNs' perceptions of drivers of engagement and their actual level of workplace engagement, Rivera et al found that nurse managers play a critical role in employee engagement and that effective leadership was more important to employees' engagement than even wages or nonmonetary work benefits. ${ }^{44}$ Rivera et al also linked employee engagement to reduced turnover, improved patient satisfaction, "higher total shareholder returns, and overall business success." ${ }^{44}$ Given that the relationship between the nursing work environment and desired patient outcomes, such as decreased mortality, patient safety, and shorter hospital lengths of stay, is thoroughly documented in the literature, ${ }^{49,50}$ and understanding leadership's pivotal role in creating such an environment, ${ }^{51-53}$ the importance or the power of effective nursing leaders should not be underestimated. That being said, in spite of the overwhelming evidence in the literature linking effective leadership with improved patient outcomes, increased staff engagement, and reduced turnover rates, research also shows that there is a general neglect of succession planning and leadership development of the frontline nurse ${ }^{37}$ and that many organizations are still not investing in the leadership development of either their current or future leaders. ${ }^{49,54}$

\section{Where do (nurse) leaders come from?}

It is not uncommon for nurses to find themselves in positions of leadership without having made a conscious decision to attain these, or even having a clear understanding of how they arrived in the positions. Many new nurse leaders find that they have been promoted into leadership in part because of their clinical expertise and/or years of service in an organization. ${ }^{39,54,55,56}$ Although it is generally assumed that good nurse leaders have at their foundation a history of clinical competency and proficiency, the inverse does not necessarily hold true; not all clinically competent and proficient nurses make good nurse leaders. ${ }^{37,55,57}$ Another unfortunate commonality among nurse leaders is a haphazard, unsystematic, trial and error lessons in leadership, they receive. ${ }^{39,58}$

Bondas conducted a study of 68 nurse leaders in Finland using a semi-structured survey in an attempt to identify the reasons why nurses choose leadership careers. ${ }^{49}$ Bondas' research identified four distinct paths to nursing leadership: the path of ideals, the career path, the path of chance, 
and the temporary path. Bondas found that a nurse who becomes a leader via the path of ideals has done so only after great introspection, not only about the pros and cons of taking on a formal leadership role but also about his or her capabilities as a leader. Path of ideals leaders want to use their position(s) of leadership to create an idealistic work unit not only to embrace best practices in health care but also to create a work environment in which both patients and staff can thrive. In contrast, career path leaders are selfidentified leaders who are ambitious, self-confident, driven, and verbalize the need to be challenged in their work. Career path leaders also seek and enjoy the power and privilege afforded leadership, such as autonomy, self-decided work hours, visibility within the organization, and remuneration. Whereas career path leaders strongly identify themselves as leaders and actively seek out leadership roles, path of chance leaders never aspired or planned to become leaders. Path of chance leaders report being shepherded toward leadership by people who recognized leadership qualities in them that they themselves could not see. Even though path of chance leaders never initially think of themselves as leaders, over time they eventually grow to embody the role and become capable nurse leaders. Finally, temporary path leaders are leaders who adopt a leadership role on a trial basis with the intention to return to bedside nursing. Although temporary path leaders report that their selfperceived leadership abilities and organizational and people skills gave them the courage to trial the leadership role, they want to maintain the option to return to the bedside, and frequently do so.

Bondas identified that $54.4 \%$ of the nurse leaders surveyed followed the path of chance to their current leadership role. ${ }^{49}$ This finding empirically substantiates the anecdotal observations currently referenced in the nursing literature. Although Bondas reports that path of chance leaders eventually come to accept their leadership identity and to function well as leaders, she also reports an initial "laissez-faire mentality [that] is not furthering the visionary leadership and development of the modern evidenced-based nursing and cooperation." If Bondas' findings are representative and can be applied to the general population of nurse leaders outside the Finnish health care system, there is cause for concern. With a clear majority of nurse leaders neither initially identifying with nor seeking a leadership persona, and with no clear concept of how long it takes for a path of chance leader to come to terms with and/or embrace his or her leadership identity, one could surmise that the impact on patient care, staff satisfaction, and, ultimately, the fiscal health of health care organizations is significant.

Perhaps more telling than the four paths to leadership identified by Bondas is the one path not identified. ${ }^{49}$ Although the path of ideals and the career path are characterized by aspiring nurse leaders, who actively seek out learning opportunities, and the path of chance references the presence of mentors and/or people who provide guidance and support, conspicuous by its absence is any reference to participating in structured leadership development programs or the perception of being purposefully groomed for leadership. Even though this study was conducted within the Finnish health care and educational system, so the question remains if Bondas' findings are transferrable to other countries, the findings are suggestive not only of a general lack of awareness in the health care industry of what motivates nurses to become leaders but also of a lack of recognition that there is an association between a nurse's motivation and chosen path to leadership and the quality of care delivery. It also highlights missed opportunities by health care organizations to illuminate the leadership path by creating a work culture in which leadership becomes an integral part of nursing competencies and identity, as well as to develop bedside nurses who are fully empowered to lead "within the confines of their position or authority." 55

\section{Why discuss unions?}

Krugman, Nobel Prize Laureate in economics, professor of economics at Princeton, and New York Times columnist, argues that even though labor unions are believed to be dying a natural death due to the influences of globalization and advances in technology, they have actually been under assault by corporate America since the $1970 \mathrm{~s} .{ }^{59}$ The dwindling union presence is evidenced by longitudinal data that show US labor union membership, in the public and private sectors combined, has dropped precipitously since 1955 to its current low of $\sim 12 \%{ }^{60-63}$ Krugman also reports that among private-sector employees, only $7.4 \%$ were represented by unions in 2007.

Many politicians and business leaders summarily dismiss claims that unions have any benefit to either business or society; ${ }^{64}$ however, while some may embrace the notion that organized labor is in its final death throws, any claims to victory may be premature. While baby boomers age and the nursing shortage gains momentum, while organizational leaders across industries grapple with managing in what some may call interesting political and economic times, and 
while there is a well-documented decline in general union membership, nursing unions are steadily increasing their constituency in the USA. ${ }^{63,65-69}$ According to the Bureau of Labor Statistics, ${ }^{60}$ in 2010 union membership density for RNs was calculated at $20.4 \%$. This reflects an increase from $18.4 \%$ in 2006 and is well above the $13.1 \%$ national average for all wage and salary workers. ${ }^{60,62}$ Given that nursing unions are relative newcomers to the labor movement, this trend is significant. The right of hospital workers to join unions and participate in collective bargaining activities was first recognized by the National Labor Relation Board (NLRB) in 1967. ${ }^{68}$ It was not until 1974, when Congress amended the National Labor Relations Act (NLRA), also known as the Wagner Act of 1935, and extended the right to organize and strike - with significant caveats - to health care workers who work both for profit and nonprofit health care organizations. ${ }^{67,68,70}$

\section{Why nurses unionize}

In the 34 years since being granted the right to organize by the NLRA, nurses have set themselves apart from other labor cohorts in that the motivation to unionize has become more focused on patient care rather than on wages and benefits. ${ }^{7,9,63,65,68}$ Both Budd et $\mathrm{al}^{9}$ and Cole Beebe ${ }^{65}$ have suggested that while nurses who are represented by a collective bargaining unit can and do negotiate for wages and other traditional labor goals, they also bargain as professionals to uphold the standards of the nursing profession. Cole Beebe further asserts that nurses are also willing to trade off monetary gains to secure working conditions that are conducive to safe patient care. Cole Beebe estimates that the union hourly wage premium for a medicalsurgical RN is 5.5\%. When compared with the $13.8 \%$ US hourly wage premium for all workers represented by a union in 2003-2007, ${ }^{71}$ the difference is clear and significant.

The nursing shortage and the increased demand for health care services are identified as the root causes behind nurses seeking collective bargaining representation., ${ }^{9,65,72}$ Nurses read the health care industry's response to the nursing shortage, the economic recession, recent changes to Medicare reimbursement, and health care reform as one that adopts a private-sector business mentality with its focus on lowering costs and increasing productivity. ${ }^{65,73}$ Craft Morgan and Lynn state that "[i]n the context of shortage, the aspects of nursing that are the most rewarding are the aspects that are most often sacrificed in the interest of 'getting the job done'."7 Nurses see this shift to a business-model approach to care delivery manifested at the bedside in the form of decreased nurse-to-patient ratios, increased use of unlicensed personnel, increased use of floating between patient care areas, ${ }^{65,72,74}$ and an overreliance on mandatory overtime to fill staffing needs. ${ }^{9,72}$ Add into this mix a significantly increased patient acuity ${ }^{73,74}$ and the result is a group of discouraged professionals who feel they have been stretched to the limit and believe that they cannot do any more with any less without jeopardizing the health and safety of their patients. ${ }^{7,9,63,70}$ Job dissatisfaction is not only cited as reason new nurses leave the direct patient care environment; ${ }^{75,76}$ it is also cited as the primary driver behind nurses entering into collective bargaining agreements. ${ }^{63,77,78}$

The existence of labor unions can be thought of as a symptom of organizations that are sick or broken. By definition, when organizations treat workers fairly and proactively address pay and benefits, when workplace conditions and work-life balance issues are addressed, and when leadership effectively communicates and engages staff, workers have no functional need for unions. ${ }^{61,67,77,79}$ That said, journals and websites are populated with literature focused on preventing and/or dissipating union activity and, when prevention fails, meeting the challenges of leading in an adversarial union environment. However, there is now a growing body of research devoted to establishing labor-management partnerships to achieve organizational and industry-wide goals. A key component to these proposals, regardless of industry, is engaging the workforce in the pursuit of organizational goals. ${ }^{51,80-83}$ To encourage workforce engagement, organizations are recommended to "enhance the working relationships by including transparency, information sharing, open communication, mutual respect, fairness on both sides, improved communication and follow-up, and mutual input into decision making." 51 Interestingly, had these healthy communication practices been present in ailing organizations to begin with, there would be no need for a bargaining unit presence.

\section{Discussion}

Developing nurse leaders in a unionized environment presents unique challenges that are beyond those traditionally experienced in nonunion settings. Thus far, this literature review has identified multiple factors contributing to the increase of nursing union membership, including the aging population, the resultant nursing shortage, and the welldocumented relationship between leadership and staff engagement. The literature review has also revealed multiple opportunities for improvement regarding the use of formal succession plans and leadership development in health care 
organizations, and has attempted to connect the indelible dots between effective leadership and quality care delivery outcomes. Each of these factors, when considered individually, is cause for concern; when considered collectively, however, they should be cause for alarm.

Nurses are trained to be good in crises. When a patient goes bad, an experienced nurse quickly and instinctively assesses both the patient and the background situation for contributing factors. The nurse then asks the right questions, enlists the skills and insights of the right experts, and, once the pertinent data have been collected and evaluated, proceeds to action. However, when the "patient" is an organization, and when the crisis is unfolding in slow motion, nursing leadership does not consistently demonstrate the same instinctual ability to either accurately recognize the current trends as symptoms of a larger crisis or the ability to apply the nursing process to a crisis occurring in a broader organizational context. In keeping with the nursing process, what follows is a series of questions and proposed answers that leadership should consider before developing an actionable plan to increase the pool of nurses who are not only able but willing to seek leadership roles outside of the bargaining unit structure.

\section{What will the nursing workforce look like?}

The literature strongly suggests that the nursing workforce is aging, and although the raw number of nurses is shown to be increasing, the supply is projected to fall short of the number needed to care for a simultaneously aging population. The literature also links the nursing shortage to work conditions that contribute to increased job dissatisfaction; furthermore, job dissatisfaction is identified as the primary driver in the increase of nurses seeking bargaining-unit representation and protection.

The literature also suggests that, notwithstanding the potential ethical and political implications that are outside the scope of this review, foreign-born nurses will continue to be an important part of the nursing shortage solution. As of $2005,15 \%$ of all US health care workers were foreign born and $25 \%$ of all physicians were also born abroad. ${ }^{32}$ Given the nursing shortage projections, there is likely to be a continued increase in foreign talent and leadership must be as sensitive to the cultural backgrounds of its foreign-born nurses as it is in meeting the cultural needs of patients. Although the potential organizational benefits of workplace diversity are well documented and the evidence shows that effectively managing workplace diversity can enhance organizational performance, ${ }^{61}$ there are challenges associated with leading in an environment in which there is an influx of foreign-born nurses who have not yet acclimated to living and working in the US culture. Gomez-Mejia et al state that these challenges include "appropriately valuing employee diversity, balancing individual needs with group fairness, dealing with resistance to change, ensuring group cohesiveness and open communication, avoiding employee resentment and backlash, retaining valued performers, and maximizing opportunity for all." ${ }^{61}$

Assuming the current trends continue, the nursing workforce now and in the immediate future will be leaner in number, older (with all the associated benefits and burdens of age), increasingly diverse, and increasingly unionized. Combined, these factors will limit the pool of nurses from which to recruit potential leaders.

\section{What changes are needed in organizational thinking?}

Carman et al report a crisis in leadership not only at the top of organizations but also at the bottom and middlemanagement levels. ${ }^{5}$ They further report that formalized succession planning is critical not only to recruitment and retention efforts but also to the improvement of employee satisfaction and engagement. Although an unstructured and/or informal approach to leadership development and succession planning has seemingly sufficed thus far, it will not be able to meet the complex needs of health care organizations going forward. Whereas in the past there has been a ready supply of talent from both inside and outside the organization to choose from, this talent pool is shrinking. Furthermore, relying on recruiting ready-made nurse leaders from outside sources is no longer as viable an option it once was, as organizations across industries are facing similar human resource challenges.

Valentine asserts that "[n]ursing as a profession does a disservice to new nurses by not developing their leadership capabilities." ${ }^{55}$ This observation has been consistently born out in the literature. Research shows that frontline leaders are the least prepared in terms of both education and experience to handle the expectations of their leadership role and frequently learn on the job by trial and error. ${ }^{37,57}$ Both Fulks and Thompson ${ }^{57}$ and Stichler ${ }^{37}$ support Bondas ${ }^{49}$ in stating that many nurse leaders find themselves in leadership roles unintentionally and are not prepared to be leaders.

Nursing programs provide varying amounts of leadership theory and training in the classroom, and as with clinical skills, the bulk of learning is expected to be continued and reinforced on the job, at the bedside..$^{55}$ The clinical and technical competency of nurses are continually measured, 
documented, nurtured, and honed, in the workplace, but there is no practical follow-up or formal competency requirement in the clinical environment for the acquisition and maintenance of leadership skills. ${ }^{55}$ Bernthal and Wellins suggest that nurturing leadership potential early will create a larger pool of leaders in the future. ${ }^{3}$ Continually honing leadership skills will also result in a staff that is more engaged, personally accountable, and able to lead when called upon.

Not all nurses are born leaders or even aspire to be leaders, but all nurses can learn to become leaders "within the confines of their position or authority." 55 Kouzes and Posner assert that "[1]eadership is everyone's business" at every level in an organization, and further emphasize the importance of gaining leadership skills as an active, ongoing process. ${ }^{84}$ Providing leadership competencies, such as communication, conflict resolution, and working in teams, in the same manner that clinical skills, new technology, and policies, are taught, practiced, and monitored is an important first step in creating a culture of leadership in health care organizations. However, research shows that leadership is best learned by doing, ${ }^{43}$ therefore, the importance of providing leadership opportunities within the organization should not be overlooked as a means to reinforce the skills taught in the classrooms and learning laboratories.

Organizations can no longer afford to leave leadership to chance. Path of chance leadership and ad hoc succession planning that once sufficed in the health care environment no longer reliably translates into effective leadership that drives the quality outcomes now demanded by the payers and our citizens. A shift in organizational thinking to one that treats leadership competency with the same seriousness as clinical competency is paramount to successfully creating a leadership culture and filling the pipeline with quality potential leaders.

\section{What are the barriers to leadership opportunities in a union environment?}

Lawson et al state that finding creative and cost effective ways to attract, retain, reward and develop the nursing workforce in times of nursing shortage is challenging. ${ }^{85}$ Further, they state that programs such as clinical ladders, are especially difficult to implement in a collective bargaining environment. ${ }^{85} \mathrm{~A}$ history common to unionized organizations is the perception by workers that the psychological contract has been violated by leadership. ${ }^{79}$ Regardless the length of time an organization has been unionized, or where the organization exists on the continuum between collaborative and aggressive behaviors, this breakdown of trust and the resulting dichotomy is a permanent part of the collective organizational memory. The resulting dichotomous "us-versus-them" mentality ingrained in the organizational culture will continue to color the communication and collaborative efforts in varying degrees throughout the lifetime of the relationship.

Experts agree that that developing leadership competency is most effectively accomplished experientially. ${ }^{37,43,54}$ Providing leadership opportunities for the rank-and-file nurse, however, can present challenges in a collective bargaining environment, ${ }^{85,86}$ not only because of the longstanding "union dogma" of equal pay for equal work ${ }^{87}$ but also because union contracts and well-defined job descriptions promote the adherence to this concept of equal work for equal pay. Simply stated: because union organizations are less likely to have individual incentive plans, union workers are more likely to be discouraged from taking on uncompensated responsibilities that reside outside of their job descriptions or the bargaining unit agreement. 88,89

Further formalizing the us-versus-them mentality that contributes to the barriers to leadership opportunities for nurses working in a union environment are the provisions set forth in the NLRA and supported by NLRB rulings. Just as there are those who argue that the profession of nursing and union membership are incompatible and mutually exclusive philosophical ideals, the roles of supervisor and employee are determined to be mutually exclusive categories as defined by the NLRA. Supervisors have been expressly excluded from bargaining-unit participation since the 1947 amendment to the NLRA. ${ }^{90}$ In 2006, the NLRB significantly broadened the definition of "supervisor" and ruled that RNs who serve as permanent charge nurses are "statutory supervisors" and are therefore are likewise excluded from the bargaining unit and NLRA protection. ${ }^{91}$ The NLRB language also leaves open the possibility for rotating charge nurses to be categorized as supervisors, depending on the percentage of work time spent performing charge nurse duties.

Fulks and Thompson describe the role of charge nurses as "small unit tactical leaders" that forms the backbone of health care organizations. ${ }^{57}$ The charge nurse role is frequently the first formal opportunity a nurse has to exercise leadership abilities. As a result of the 2006 NLRB ruling that defined permanent charge nurses as supervisors, unionized health care organizations rotate charge nurse assignments daily. Fulks and Thompson report that clinical nurses promoted to traditional permanent charge nurse positions in the nonunion setting are frequently ill equipped for the associated leadership responsibilities. One could then assume that bargaining unit nurses who rotate charge nurse 
responsibilities are equally ill equipped but are also less likely to identify with their transient leadership role. The difficulty in developing charge nurses' leadership abilities in an ad hoc environment is likewise understood.

Even though the us-versus-them mindset lingers in the organizational memory, and the 2006 NLRB ruling further divorces the leadership role from the bargaining unit, dual loyalty to both the bargaining unit and health care organization, and leader-member partnerships are possible. After reviewing the literature spanning 37 years, Barling et al concluded that an allegiance between a bargaining unit and organization is possible but highly dependent on the health of the relationship between them. ${ }^{77}$ Barling et al's findings are dated but remain relevant and are supported in current literature. In their study examining nurse satisfaction in a bargaining unit environment, Seago et al concluded that in spite of lower job satisfaction reported by bargaining unit nurses and the adversarial relationship present in a union environment, with "open and effective management and leadership" a good working relationship is possible between labor and management, regardless of bargaining unit presence. ${ }^{69}$ Porter further suggests that by keeping all labor-management discussions patient focused, management and labor mutually assumes the risk of working together and, in so doing, the us-versus-them perspective can be removed from both sides. ${ }^{82}$ Porter also asserts that "clinical nurses in nursing unions are leaders of nurses as well," and further suggests that bedside nurses can assume leadership roles in nursing practice, outside of the charge nurse role, through quality work, participating in evidence-based practice projects, heading charity fundraising teams, and functioning as mentors and preceptors.

The literature suggests that developing nurse leaders in a bargaining unit environment will continue to be a challenge until leader-member partnerships cease being the exception and become the rule. The 2006 NLRB ruling excluding charge nurses from union membership further formalizes the us-versus-them paradigm and effectively subverts the ability for organizations to provide direct leadership learning opportunities for nurses working in the bargaining unit. The NLRB ruling is viewed by some as driving a wedge between parties in the leader-member relationship at a time when teamwork is essential to achieve results-driven outcomes in patient care delivery systems. ${ }^{92}$ In the absence of a permanent charge nurse position that once provided a natural segue between labor and leadership, organizations with active bargaining units must be creative in providing learning opportunities for their members to practice leadership skills without violating either contract or labor laws established by the NLRA.

\section{Recommendations for future research}

The review of currently available research revealed a scarcity of scholarly work on nurses within bargaining units who transition from the bedside to nonunion leadership positions. There is ample parallel research devoted to developing nurse leaders from the front line in nonunion environments, as well as developing union leadership from within the bargaining unit proper, but little attention has been dedicated to either exploring the development of nurse leaders from within the union environment or the factors contributing to their decision to leave the structure, safety, and seniority benefits of the bargaining unit to take on a unprotected nonunion leadership role. Also absent from the literature is research identifying the potential challenges new leaders face when leading in the union environment in which they were previously a member. These questions must be answered to accurately identify the psychosocial barriers that union nurses perceive when presented the opportunity to take on leadership roles outside of their bargaining unit. Insight into these issues is also necessary to mediate the negative effects of the perceived barriers, thereby increasing the pool of union nurses who see leadership as a viable and desirable career path.

Also absent from the literature, but equally important, is the impact of transient leadership on care delivery and unit cohesion. The 2006 NLRB ruling excluding the permanent charge nurse role from collective bargaining unit protection has resulted in the increased use of a rotating charge nurse. Given that charge nurses directly communicate and coordinate care with patients and their families, staff, physicians, and support departments, the importance of their leadership, or lack thereof, to patient outcomes, staff satisfaction, and unit cohesion should not be ignored. Fulks and Thompson express concern regarding the health care industry's current trend to "throw our clinical nurses into leadership positions ... with little or no preparation." ${ }^{57}$ As previously stated, it could then be assumed that bargaining unit nurses who are assigned charge nurse responsibilities on a rotating basis will be not only equally unprepared but also less likely to identify with their transient leadership role. The charge nurse role, rotating or otherwise, will continue to be the first formal leadership position a nurse will experience. If the nurse is both assigned to and ill prepared for leadership, he or she will probably have a stressful and dissatisfying experience. 
Further study is therefore suggested to explore the effects of transient leadership and the rotating charge nurse on patient care delivery, staff satisfaction, and unit cohesion.

\section{Conclusion}

The current nursing shortage is real, the effects profound, and the solutions complex and elusive. Baby boomers represent a disproportionate segment of the nursing workforce and, as an aging cohort, they are being collectively asked to postpone their retirement to care for a simultaneously aging population. When they finally do leave the workforce - and they will not only will they be figuratively trading in the bedside for the hospital bed, they will also be trading in their university lecterns, the boardroom chair, and their administrative and management offices. The vacancies baby boomer nurses leave behind will have an impact not only on the staffing at the front line but also at all levels of leadership in health organizations..$^{55}$

Further compounding the effects of the current nursing shortage is the general neglect health care organizations have shown to the importance of succession planning and leadership development, not only at the executive level but also extending to the frontline leaders. In the context of the current economic, social, and political environment in which both fiscal and human resources are limited and the clear relationship between effective leadership and organizational outcomes, lack of foresight and planning is a luxury the health care industry can no longer afford.

The literature also reveals that the workplace conditions in health care organizations have been further challenged by the current nursing shortage, political and economic environment, and health care reform. The increased demands on an older and smaller nursing workforce have resulted in increased job dissatisfaction among nurses and have likewise created an environment favorable to increased collective bargaining activity. Once the psychological contract and trust has been broken between nurses and leaders and the us-versus-them paradigm is adopted, it is never fully forgotten, even in the seldom-occurring instances where leader-member collaborative partnerships are sought and achieved.

Any discussion involving labor unions is likely to be polarizing. Philosophical lines are drawn and sides are chosen. The ensuing discourse frequently perpetuates dichotomous reasoning that is ineffectual in finding meaningful solutions to complex organizational problems. Good/Bad, yes/no, and black/white solutions sought in an us-versus-them environment are not serviceable when "we" results are not only required, but demanded by regulatory bodies and our citizenry. Collective bargaining unit leaders fear that collaborative or participative activities will result in weakened member loyalty and commitment $;{ }^{93}$ management fear that concessions made to the bargaining unit will further impede their freedom to manage ${ }^{64,67}$ however, neither position has been definitively born out in the literature when objectively vetted and both positions must be set aside if the answers to preventing the leadership crisis in the context of increased union presence fueled by the nursing shortage are to be found.

\section{Disclosure}

The author declares no conflicts of interest in this work.

\section{References}

1. Howden LM, Meyer JA. Age and Sex Composition: 2010. Washington DC: US Census Bureau; May 2011. Available from: http://www. census.gov/prod/cen2010/briefs/c2010br-03.pdf. Accessed June 30, 2011.

2. Greenblatt A. Aging baby boomers: will the "youth generation" redefine old age? CQ Researcher. 2007;17(37):865-888. Available from: http://www.agingsociety.org/agingsociety/publications/public_policy/ cqboomers.pdf. Accessed May 15, 2011.

3. Bernthal P, Wellins R. Trends in leader development and succession. Human Resource Planning. 2006;29(2):31-40.

4. Santora JC, Caro ME, Sarros, JC. Succession in nonprofit organizations: an insider/outsider perspective. SAM Advanced Management Journal. 2007;72(4):26-31.

5. Carman JG, Leland SM, Wilson AJ. Crisis in leadership or failure to plan? Nonprofit Manag Leadersh. 2010;21(1):93-111.

6. Cullen E, Janji U, Salganicoff A. Nursing workforce: background brief [web page on the Internet]. Menlo Park, CA: Kaiser Family Foundation, KaiserEDU.org; Nov 2010. Available from: http://www.kaiseredu.org/ Issue-Modules/Addressing-the-Nursing-Shortage/Background-Brief. Accessed June 29, 2011.

7. Craft Morgan J, Lynn MR. Satisfaction in nursing in the context of shortage. J Nurs Manag. 2009;17(3):401-410.

8. Atwater DM, Jones A. Preparing for a future labor shortage. How to stay ahead of the curve. Graziadio Business Review [serial on the Internet]. 2004;7(2):[about 7 p]. Available from: http://gbr.pepperdine. edu/2010/08/preparing-for-a-future-labor-shortage/. Accessed June 29, 2011.

9. Budd KW, Warino LS, Patton ME. Traditional and non-traditional collective bargaining: strategies to improve the patient care environment. Online J Issues Nurs. 2004;9(1):9.

10. Cadmus E. Succession planning: multilevel organizational strategies for the new workforce. J Nurs Adm. 2006;36(6):298-303.

11. Stokowski L. Trends in nursing: 2004 and beyond. Medscape Nurses News. Topics in Advanced Practice Nursing eJournal. 2004;4(1). Available from: http://www.medscape.com. Accessed June 29, 2011.

12. Han GH, Jekel M. The mediating role of job satisfaction between leadermember exchange and turnover intentions. J Nurs Manag. 2011;19(1): 41-49.

13. Barclay L. Retaining older nurses in hospital practice: a newsmaker interview with Barbara J Hatcher, PhD, RN, MPH. Medscape Medical News. June 21, 2006. Available from: http://www.medscape.com/ viewarticle/537115. Accessed June 3, 2011.

14. Buerhaus PI, Auerbach DI, Staiger DO. The recent surge in nurse employment: causes and implications. Health Aff (Millwood). 2009; 28(4):w657-w668. 
15. Moye JP, Swan BA. Growing ambulatory care nurse leaders in a multigenerational workforce. Nurs Econ. 2009;27(6):408-411, 415.

16. Wing P, McGinnis T, De A. Toward a Method for Identifying Facilities and Communities with Shortages of Nurses. Rensselaer, NY: Center for Health Workforce Studies at the School of Public Health at the University of Albany; 2007. Available from: http://bhpr.hrsa.gov/healthworkforce/ reports/methindentifysummary.pdf. Accessed June 3, 2011.

17. Arias E. United States life tables, 2006. Natl Vital Stat Rep. 2010;58(21): $1-40$.

18. Stein PJ. Aging workforce in the United States: Trends and Challenges [slide presentation]. Chapel Hill, NC: UNC Institute on Aging; 2010. Available from: http://www.aging.unc.edu/infocenter/slides/SteinEC presentation060310.ppt. Accessed May 30, 2011.

19. US Census Bureau. Civilian labor force-percent distribution by sex and age: 1980 to 2009 [table]. In: US Census Bureau. Statistical Abstract of the United States: 2011. Washington DC: US Census Bureau; 2011: 381. Available from: http://www.census.gov/compendia/statab/2011/ tables/11s0591.pdf. Accessed June 3, 2011.

20. Buerhaus PI, Staiger DO, Auerbach DI. Is the current shortage of hospital nurses ending? Health Aff (Millwood). 2003;22(6):191-198.

21. Nursing Managements Aging Workforce Survey 2006. Nurs Manag. February 2006;37(4):9-10.

22. American Association of Colleges of Nursing (AACN). Nursing Faculty Shortage Fact Sheet. Washington DC: AACN; 2012 [updated March 21]. Available from: http://www.aacn.nche.edu/media-relations/FacultyShortageFS.pdf. Accessed July 23, 2012.

23. Auerbach DI, Buerhaus PI, Staiger DO. Better late than never: workforce supply implications of later entry into nursing. Health Aff (Millwood). 2007;26(1):178-185.

24. US Bureau of Labor Statistics. Overview of the 2010-2020 projections. In: US Bureau of Labor Statistics. Occupational Outlook Handbook (2010-2011 edition). Washington DC: US Bureau of Labor Statistics; December 3, 2010. Available from: http://data.bls.gov/cgi-bin/print.pl/ oco/oco2003.htm. Accessed June 28, 2011.

25. U.S. Department of Health and Human Services Health Resources and Services Administration. The Registered Nurse Population. Findings from the 2008 National Sample Survey of Registered Nurses. Available from http://bhpr.hrsa.gov/healthworkforce/rnsurveys/rnsurveyinitial2008.pdf. Accessed August 12, 2012.

26. Wieck K, Dols J, Landrum P. Retention priorities for the intergenerational nurse force. Nurs Forum. 2010;45(1):7-17.

27. Katigbak J. Filipino nurses still rule the roost in US [web page on the Internet]. Mandaluyong City: philSTAR.com; September 28, 2008. Available from: http://www.philstar.com/ArticlePrinterFriendly. aspz?articleId=403401. Accessed June 3, 2011.

28. American Association of Retired Persons (AARP). AARP issue brief: nursing shortage [web page on the Internet]. Washington DC, AARP; 2010. Available from: http://www.aarp.org/politics-society/governmentelections/info-02-2009/aarp_issue_brief_nursing_shortage.html. Accessed June 3, 2011.

29. Buerhaus PI, Staiger DO, Auerbach Dl. The Future of the Nursing Workforce in the United States. Sudbury, MA: Jones and Bartlet Publishers LLC; 2009.

30. New AACN data show the impact of the economy on the nurse faculty shortage [press release]. San Francisco, CA and New York, NY: Business Wire; September 18, 2009. Available from: http://www.thefreelibrary. com/_print/PrintArticle.aspx?id=208034313. Accessed June 15, 2011.

31. LaRocco, SA: Who will teach the nurses? Academe Online. 2006; 92(3). Available from www.aaup.org/AAUP/pubsres/academe/2006/MJ/feat/ laro.htm?PF=1. Accessed August 19, 2012.

32. Clearfield E, Batalova J. Foreign-born health-care workers in the United States [web page on the Internet]. Washington DC: Migration Information Source; February 1, 2007. Available from: http://www.migrationinformation. org/USFocus/print.cfm?ID=583. Accessed April 8, 2011.

33. workpermit.com. US looks abroad for nurses, especially to Philippines [web page on the Internet]. London: workpermit.com; March 6, 2006. Available from: http://www.workpermit.com/news/2006_03_06/us/ us_hires_foreign_filipino_nurses.htm. Accessed May 6, 2011.
34. Health Professions Networks Nursing and Midwifery Office. A Global Survey Monitoring Progress in Nursing and Midwifery. WHO/HRH/ HPN/10.4. Geneva: World Health Organization; 2010. Available from: http://whqlibdoc.who.int/hq/2010/WHO_HRH_HPN_10.4_eng.pdf. Accessed June 3, 2011.

35. McIntosh B, Palumbo M V, Rambur B. Does a "shadow workforce" of inactive nurses exist? Nurs Econ. 2006;24(5):231-237.

36. Williams KA, Stotts RC, Jacob SR, Stegbauer CC, Roussel L, Carter D. Inactive nurses: a source for alleviating the nursing shortage? $J$ Nurs Adm. 2006;36(4):205-210.

37. Stichler JF. Succession planning: why grooming their replacements is crucial for nurse leaders. Nurs Womens Health. 2008;12(6): $525-528$.

38. Barnett R, Davis S. Creating greater success in succession planning. Advances in Developing Human Resources. 2008;10(5):721-739.

39. Ganz NR. 101 Global Leadership Lessons for Nurses. Indianapolis, IN: Sigma Theta Thau International Publishing; 2009.

40. Walker DM. Nonprofit, for Profit, and Government Hospitals: Uncompensated Care and Other Community Benefits [testimony]. GAO05-743T. Washington DC: US Government Accountability Office; 2005. Available from: http://www.gao.gov/new.items/d05743t.pdf. Accessed June 3, 2011.

41. Garman NA, Tyler JL. Succession planning and practices and outcomes in U.S. hospital systems: Final report; August 20, 2007. Available from: HYPERLINK "http://www.ache.org/pubs/research/succession_planning.pdf" www.ache.org/pubs/research/succession_planning.pdf

42. Lee BD, Herring JW. Growing Leaders in Healthcare: Lessons from the Corporate World. Chicago, IL: Health Administration Press; 2009.

43. Cappelli P. A supply chain model for talent management. People and Strategy. 2009;32(3):4-7. Available from: http://www.thefreelibrary. $\mathrm{com} / \mathrm{A}+$ supply+chain+model+for+talent+management.- a0210520025. Accessed June 29, 2011.

44. Rivera RR, Fitzpatrick JJ, Boyle SM. Closing the RN engagement gap: which drivers of engagement matter? J Nurs Adm. 2011;41(6): 265-272.

45. CMS.gov. Centers for Medicare and Medicaid Services: nd. Hospital quality initiative Available from http://www.cms.gov/Medicare/ Quality-lnitiatives-Patient-Assessment-lnstruments/HospitalQualitylnits/index.html?redirect=/HospitalQualitylnits/. Accessed August 19, 2012.

46. Bazzoli F. Final CMS rule adds "never events" that Medicare won't pay for. Healthcare Finance News. August 4, 2008. Available from: http:// www.healthcarefinancenews.com. Accessed June 3, 2011.

47. Hewison A. Do we expect too much from our leaders? J Nurs Manag. 2009;17(8):913-916.

48. Sellgren S, Ekvall G, Tomson G. Nursing staff turnover: does leadership matter? Leadersh Health Serv (Bradf Engl). 2007;20(3):169-183.

49. Bondas T. Paths to nursing leadership. J Nurs Manag. 2006;14(5): 332-339.

50. Kramer M, Schmalenberg C, Maguire P. Nine structures and leadership practices essential for a magnetic (healthy) work environment. Nurs Admin Q. 2010;34(1):4-17.

51. Porter CA, Kolcaba K, McNulty R, Fitzpatrick JJ. The effect of nursing labor management partnership on nurse turnover and satisfaction. J Nurs Adm. 2010;40(5):205-210.

52. Wolf GA, Bradle J, Greenhouse P. Investment in the future: a 3-level approach for developing the healthcare leaders of tomorrow. $J$ Nurs Adm. 2006;36(6):331-336.

53. Wong C, Cummings G. Authentic leadership: a new theory for nursing or back to basics? J Health Organ Manag. 2009;23(5):522-538.

54. Sherman R, Pross E. Growing future nurse leaders to build and sustain healthy work environments at the unit level. Online J Issues Nurs [serial on the Internet]. 2010;15(1):[about 9p]. Available from: http://www. medscape.com/viewarticle/723409m. Accessed June 3, 2011.

55. Valentine SO. Nursing leadership and the new nurse. Journal of Undergraduate Nursing Scholarship. 2002;4(1):[about 4 p]. Available from: http://www.juns.nursing.arizona.edu/articles/Fall\%202002/ Valentine.htm. Accessed June 3, 2011. 
56. Avery E, Gerber M. The transition to nurse manager. New York Nurse. September 2008. Available from: http://www.nysna.org/publications/newyorknurse/2008/sept/nurse_mgr.htm. Accessed June 3, 2011.

57. Fulks C, Thompson J. Charge Nurses: Investing in the Future. Lenexa, KS: BE Smith; 2008. Available from: http://www.nursingcenter.com/upload/ static/1252649/BESmithWhitePaper1.pdf. Accessed June 3, 2011.

58. Studer Group. The Nurse Leader Handbook: The Art and Science of Nurse Leadership. Gulf Breeze, FL: Fire Starter Publishing; 2010.

59. Krugman P. State of the unions. New York Times. December 24, 2007. Available from: http://www.nytimes.com/2007/12/24/opinion/24krugman. html. Accessed June 29, 2011.

60. US Bureau of Labor Statistics. Union Members - 2010 [news release]. USDL-11-0063. Washington DC: US Bureau of Labor Statistics January 21, 2011. Available from: http://www.bls.gov/news.release/ pdf/union2.pdf. Accessed June 28, 2011.

61. Gomez-Meija LR, Balkin DB, Cardy, RL. Managing Human Resources. 6th ed. Upper Saddle River, NJ: Prentice Hall; 2010.

62. Hirsch BT, Macpherson DA. Index of tables: Union data compilations from the 2010 CPS [database on the Internet]. January 21, 2011. Available from: http://www.unionstats.com/. Accessed April 15, 2011.

63. Malvey D. Unionization in healthcare: background and trends. J Healthc Manag. 2010;55(3):154-157.

64. McLennan K. What do unions do? A management perspective. In: Bennet JT, Kaufman BE, editors. What Do Unions Do? A TwentyYear Perspective. New Brunswick, NJ: Transaction Publishers; 2008: 563-588.

65. Cole Beebe ME. What do nurses' unions do? Implications for RN wages, the patient care environment, and patient outcomes [dissertation]. Worcester, MA: Clark University; 2008. Available from: http:// gradworks.umi.com/33/05/3305595.html. Accessed May 15, 2011.

66. Stagg Elliot V. Unions for health care workers are growing. American Medical News. February 22, 2010. Available from: http://www.ama-assn org/amednews/2010/02/22/bisb0222.htm. Accessed June 29, 2011.

67. Oetjen RM, Oetjen DM. Labor laws: encounters with unions. In: McConnell CR, editor. The Health Care Manager's Legal Guide. Sudbury, MA: Jones and Bartlett Learning; 2011:205-222.

68. Sanders LG, McCutcheon AW. Unions in the healthcare industry. Labor Law Journal. 2010; 61(3) Fall:142-151. Available from: http:/www.bassberry. com/files/upload/LLJFall\%202010.pdf. Accessed June 3, 2011.

69. Seago JA, Spetz J, Ash M, Herrera C, Keane D. Hospital RN job satisfaction and nurse unions. J Nurs Adm. 2011;41(3):109-114.

70. Wilson CN, Hamilton CL, Murphy E. Union dynamics in nursing. J Nurs Adm. 1990;20(2):35-39.

71. Schmitt J. The Union Wage Advantage for Low-Wage Workers. Washington DC: Center for Economic and Policy Research; 2008. Available from: http://www.cepr.net/documents/publications/ quantile_2008_05.pdf. Accessed June 3, 2011.

72. New York State Nurses Association (NYSNA). Why RNs need a union (and other questions) [web page on the Internet]. Latham, NY: NYSNA; nd. Available from: http://www.nysna.org/union/rns_need. htm. Accessed June 3, 2011.

73. Moody K. As hospitals go "lean" and squeeze workers, unions see potential for organizing [web page on the Internet]. Detroit, MI: Labor Notes; March 15, 2011. Available from: http://labornotes. org/2011/02/hospitals-go-lean-and-squeeze-workers-unions-seepotential-organizing. Accessed June 3, 2011.

Journal of Healthcare Leadership

\section{Publish your work in this journal}

The Journal of Healthcare Leadership is an international, peer-reviewed, open access journal focusing on leadership for the health profession. The journal is committed to the rapid publication of research focusing on but not limited to: Healthcare policy and law; Theoretical and practical aspects healthcare delivery; Interactions between healthcare and society and evidence-based practices;
74. Currie J, Farsi M, MacLeod WB. Cut to the bone? Hospital takeovers and nurse employment contracts. Industrial and Labor Relations Review. 2005;58(3):471-493.

75. Curnayn K. Nurse unions: a collective voice [web page on the Internet]. Charlotte, NC: NurseTogether; nd. Available from: http:/www. nursetogether.com/tabid/102/itemid/1832/Nursing-Unions-A-Collective-Voice.aspx. Accessed June 3, 2011.

76. Tervo-Heikkinen T, Kiviniemi V, Partanen P, Vehviläinen-Julkunen K. Nurse staffing levels and nursing outcomes: a Bayesian analysis of Finnish-registered nurse survey data. J Nurs Manag. 2009;17(8):986-993.

77. Barling J, Fullagar C, Kelloway EK. The Union and Its Members: A Psychological Approach. New York, NY: Oxford University Press; 1992.

78. Kelly P. Nursing Leadership and Management. 2nd ed. Clifton Park, NY: Delmar Cengage Learning; 2008.

79. Turnley WH, Bolino MC, Lester SW, Bloodgood JM. The effects of psychological contract breach on union commitment. Journal of Occupational and Organizational Health Psychology. 2004;77(3): 421- 428 .

80. Gill C. Union impact on the effective adoption of high performance work practices. Human Resource Management Review. 2009;19(1):39-50.

81. Schuster $\mathrm{MH}$, Weidman S. Organizational change in union settings: labor-management partnerships: the past and the future. Human Resource Planning. 2006;29(1):45-51.

82. Porter C. A nursing labor management partnership model. J Nurs Adm. 2010;40(6):272-276.

83. Raso R. Establishing healthy union relationships and the "best" unit in the hospital. Nurs Manage. 2010;41(8):56.

84. Kouzes JM, Posner BZ. The Leadership Challenge. 4th ed. San Francisco, CA: John Wiley and Sons; 2007.

85. Lawson L, Miles KS, Vallish RO, Jenkins SA. Recognizing nursing professional growth and development in a collective bargaining environment. J Nurs Adm. 2011;41(5):197-200.

86. Murray K. Clinical ladder programs and unions; the evolution of the CNL role. Nurs Manage. 2010;41(4):56.

87. Amundson NE. Labor relations and the nursing leader. Union dogma. J Nurs Adm. 1974;4(1):14-15.

88. Freeman RB, Medoff JL. What Do Unions Do? New York, NY: Basic Books; 1984.

89. Verma A. What do unions do in the workplace? Union effects on management and HRM policies. In: Bennett JT, Kaufman BE, editors. What Do Unions Do? A Twenty-Year Perspective. New Brunswick, NJ: Transaction Publishers; 2008:275-312.

90. Labor board ruling limits union eligibility for charge nurses. Nursing Executive Watch. 2006;7(20):2-3. Available from: http://www. solutionsoutsidethebox.net/documents/Quotes/Labor_board.pdf. Accessed May 15, 2011.

91. National Labor Relations Board (NLRB). Seventy-First Annual report of the National Labor Relations Board for the Fiscal Year Ended September 30, 2006. Washington DC: NLRB; 2006. Available from: http://www. nlrb.gov/sites/default/files/documents/119/nlrb2006.pdf. Accessed June 30, 2011.

92. Kochan TA, Eaton EE, McKersie RB, Adler PS. Healing Together: The Labor-Management Partnership at Kaiser Permanente. Ithaca, NY: Cornell University Press; 2009.

93. Eaton AE, Rubenstein SA. Tracking local unions involved in managerial decision-making. Labor Studies Journal. 2006;31(2):1-29.

\section{Dovepress}

Interdisciplinary decision-making; Philosophical and ethical issues; Hazard management; Research and opinion for health leadership; Leadership assessment. The manuscript management system is completely online and includes a very quick and fair peer-review system. Visit http://www.dovepress.com testimonials.php to read real quotes from published authors. 